\title{
米価の不確実性の低減と米作の収益性
}

住本 雅洋 (神戸大学)

草苅仁 (神戸大学)

\section{Rice Farmers' Benefits from the Income Support Direct Payment Program}

\section{Masahiro Sumimoto and Hitoshi Kusakari (Kobe University)}

The income support direct payment program, which was introduced in FY 2010, mitigates the reduction of rice farmers' income caused by the recent downward trending price of rice. However, rice farmers participating in the program need to give up a part of their income from the rice production adjustment. Therefore, the net benefit of the participation in the program has been defined as the

\section{1. はじめに}

近年，米価は下落傾向にある。コメの安定供給を 図るためには，米価の不確実性を低減し，米作農家 の所得を安定化することは重要であると考光られ る. そのため, 米作所得の安定化を図る制度の導入 は一定の合理性をもつといえる。

そのような政策として，2010 年度より戸別所得 補償制度が採られている。2009 年の民主党連立政権 の成立に伴らものであり，2010 年度には戸別所得 補償モデル対策が実施され，2011年度から農業者 戸別所得補償制度となって実施されていたが，2012 年 12 月の政権交代後の 2013 年度も経営所得安定対 策と改称して，基本的に同じ枠組みのまま継続して 実施された ${ }^{1}$.

この制度に加入するためには, 生産数量目標に 従って生産することが必要であるが，作付面積など の規模要件がない，そのため，この制度は米作の構 造改革と整合していない可能性がある。これに関し て, 谷口 (2010), 藤野 (2011), 磯田 (2011) は, 『米 生産費統計』を用いた試算から，大規模層洼ぞ戸別 所得補償のメリットが大きく，規模拡大のインセン ティブとなることを指摘している，乙かし，米作農 家は, 制度に参加することによって, 生産調整のた めに失った米作所得を機会費用として負担している difference between the subsidy and the opportunity cost of the rice production adjustment. The objective of this study is to estimate the net benefit by size class of rice acreage for FYs 2010 and 2011. The results show that the program is more profitable for the middle-size class (3.0-5.0 ha) than for the largest class ( 5.0 ha and over) farms, implying that the program deters expansion of rice farm size.

ことになると考光られるが，先行研究に抢ける試算 では考慮されていない2．したがって，経営所得安 定対策等の戸別所得補償の米作農家の収益性への影 響は，生産調整のために失った米作所得を機会費用 として含めて検討される必要がある。

本稿では，米価が下落傾向にある中で，米価の不 確実性が米作所得に与光る影響の低減を目的に実施 されている経営所得安定対策（戸別所得補償）が米 作農家の収益性に及ぼす効果について考察し, 米作 の構造改革への影響について検討することを課題と する，そのため，生産数量目標の達成による機会費 用を制度加入の費用とみなして，制度加入の収入と の関係から，制度の効果について検討する。なお， 議論の簡単化のため，米作農家はリスク中立的であ ると仮定して分析を進める。

\section{2. 経営所得安定対策の概要}

2010 年度から導入されたコメの戸別所得補償制 度（2010 年度は戸別所得補償モデル対策，2011 年 度と 2012 年度は農業者戸別所得補償制度）は, 2013 年度の経営所得安定対策まで基本的に同じ枠 組久で実施された。

経営所得安定対策の主食用米に関する交付金は, 米の直接支払交付金（2010 年度は定額部分，2011 
年度と 2012 年度は米の所得補償交付金）と米価変 動補填交付金（2010 年度は変動部分，2011 年度と 2012 年度は米価変動補填交付金)からなる．前者は, 「標準的な生産費」と「標準的な販売価格」の差額 に相当する交付金で，交付単価は全国一律 15,000 円/ $10 \mathrm{a}$ である，後者は，「当年産の販売価格」が「標 準的な販売価格」を下回った場合に支払われる交付 金で，交付単価は全国一律で「当年産の販売価格」 と「標準的な販売価格」の差額であるが， $10 \mathrm{a}$ 当た りに換算して算出される.

交付対象面積は, ともに, 主食用米の作付面積か ら，自家消費米用に相当する面積として一律に $10 \mathrm{a}$ を控除した面積となる。

交付対象者は, 米の生産数量目標に従って生産す る販売農家・集落営農とされて扣り, 制度加入のた めの経営規模要件がない, また, 交付金の単価も上記 のように, 全国で一律であり, 規模間の違いはない.

米価変動補填交付金（変動部分）の交付は，これ まで，2010 年度で実績があり，交付単価は 15,100 円/ $10 \mathrm{a}$ であった. 2011 年度と 2012 年度については, 米価が基準となる「標準的な販売価格」を上回った ため，交付されなかった ${ }^{3)}$. そのため, 2010 年度で は, 定額部分と変動部分の合計である $30,100 / 10$ a (15,000 円 $/ 10 \mathrm{a}+15,100$ 円 $/ 10 \mathrm{a}), 2011$ 年度と 2012 年度では米の所得補償交付金のみの 15,000 円/10 a を交付単価として, 米作農家の所得補償がされたこ とになる。

\section{3. 分析方法}

\section{(1) 分析の枠組み}

経営所得安定対策への加入による収入と費用を比 較することにより, 米作農家に対する経営所得安定 対策加入の効果について検討する.

前節で述べたように, 経営所得安定対策の交付対 象者は, 米の生産数量目標に従って生産することが 必要である. そのため, 米作農家は, 経営所得安定 対策に加入する場合は, 制限された作付面積での米 作所得と交付金の合計を得る。すなわち,

$$
I_{R}\left(A_{0}\right)+s\left(A_{0}-10\right) / 10
$$

ただし， $I_{R}\left(A_{0}\right)$ は生産数量目標を達成するときの作 付面積 $A_{0}$ での米作所得であり, $s$ は $10 \mathrm{a}$ あたりの交 付金単価であり, 米の直接支払交付金（定額部分,
米の所得補償交付金）と，米価が基準を下回った時 の米価変動補填交付金（変動部分）の合計である. 下付き文字の 0 は制度への加入時を表す。ここで, 労働と土地を固定生産要素とする可変利潤から雇用 労賃と支払地代を控除した額が米作所得にほ淁対応 する ${ }^{4}$. そのため, 米作所得は,

$$
I_{R}\left(A_{0}\right)=\pi_{R}\left(\mathbf{p}_{0}, L_{0}, A_{0}\right)-w_{0} L_{0 h}-r_{0} A_{0 b}
$$

と表される。ただし， $\pi_{R}$ は可変利潤であり， $\mathbf{p}_{0}$ は 米価, 可変要素価格からなる価格ベクトルであり, $L_{0}$ は労㗢の投入量, $w_{0}$ は賃金率, $L_{0 h}$ は雇用労働の 投入量, $r_{0}$ は地代, $A_{0 b}$ は小作地の面積である.

一方, 経営所得安定対策に加入しないときは, 生 産数量目標に従わない場合の米作所得を得る. ここ では, 作付面積の拡大に起因する米作所得の増加の みを評価するため，米作所得は，労働の投入量は一 定として, 作付面積だけを拡大する場合を想定する.

$$
I_{R}\left(A_{1}\right)=\pi_{R}\left(\mathbf{p}_{0}, L_{0}, A_{1}\right)-w_{0} L_{0 h}-r_{0} A_{1 b}
$$

ただし， $A_{1} ， A_{1 b}$ はそれぞれ，生産数量目標に従わな い場合の作付面積と小作地の面積である。このとき の作付面積は経営耕地である田の面積とする.

したがって, 米作農家は, 経営所得安定対策へ加 入する場合，米の直接支払交付金（定額部分，米の 所得補償交付金）と，米価が基準を下回ったときの 米価変動補填交付金（変動部分）の合計 $\left(s\left(A_{0}-\right.\right.$ 10)/10)を収入として得る。 その一方で, 米作農家は, 生産調整によって失った米作所得 $\left(I_{R}\left(A_{1}\right)-I_{R}\left(A_{0}\right)\right)$ を, 生産数量目標を達成することの機会費用として負担 していることになる.

この経営所得安定対策加入の収入と費用の差を経 営所得安定対策加入の純所得と定義し, 2010 年度 と 2011 年度について規模階層間で比較することに より, 経営所得安定対策の効果について考察する.

\section{（2）推計方法}

経営所得安定対策加入の純所得は, $0.5 \sim 1.0$ ha, $1.0 \sim 2.0$ ha, $\quad 2.0 \sim 3.0$ ha, $3.0 \sim 5.0$ ha, 5.0 ha 以 上の 5 階層を対象として推計する.

まず，2010 年度と 2011 年度の制度に加入する場 合の作付面積 $\left(A_{0}\right)$ と米作所得 $\left(I_{R}\left(A_{0}\right)\right)$ はそれぞれ, 農林水産省『米及び麦類の生産』「米の作付規模別 生産費」(都府県）（10 a 当たり）から得られる 2010 年産米と 2011 年産米の作付面積と米作所得とする. 
ただし，米作所得は，主産物と副産物を合わせた粗 収益から物財費, 雇用労賃, 支払地代の合計を控除 した額とする ${ }^{5}$.

経営耕地面積まで作付した（制度に加入しない） 場合の米作所得 $\left(I_{R}\left(A_{1}\right)\right)$ は統計からは得られない. そのため，草苅・中川（2011）において計測された 可変利潤関数の推計結果 ${ }^{6)}$ を用いて推計された 2010 年度と 2011 年度の可変利潤 $\left(\pi_{R}\left(\mathbf{p}_{0}, L_{0}, A_{1}\right)\right)$ から, 雇用労賃, 支払地代, その他の費用（土地改良及び 水利費, 物件税及び公課諸負担, 生産管理費) を控 除した額に, 副産物の粗収益を加算した值を, 経営 耕地面積まで作付した場合の米作所得 $\left(I_{R}\left(A_{1}\right)\right)$ と する.

推計には, 農林水産省『米及び麦類の生産費』「米 の作付規模別生産費」（都府県）（10 a 当たり）と農 林水産省『農業物価統計』を用いた. 経営耕地面積 $\left(A_{1}\right)$ は, 経営耕地面積の田の面積を用いた. 作付 面積を経営耕地面積まで拡大したときの追加的な支 払地代の算出に用いる地代 $(r)$ は，支払小作料を 作付面積に占める小作地の比率で除して算出した ${ }^{7}$. このほかの推計に用いた各変数の作成方法は草苅・ 中川（2011）に従った.

農林水産省『米及び麦類の生産費』をみると, 規 模階層が大きい注ど作付面積に占める小作地の割合
は高くなっている，しかし，経営耕地面積の自作地 と小作地の内訳は不明であるため，制度に加入せず に作付面積を経営耕地面積まで拡大寸る場合, 追加 的な作付地の自作地と小作地の構成比がわからな い，そのため，ここでは，作付面積の追加分が，自 作地のみの場合と，小作地の場合のそれぞれについ て，推計することにする.

\section{4. 考察}

推計した経営所得安定対策加入の効果は, 表 1 の と打りである。規模階層間で比較するため，生産数 量目標を達成する場合の作付面積 $10 \mathrm{a}$ 当たりに換 算した值を示した。

まず，制度加入によって，2010 年度は定額部分 （15,000 円/10 a） と変動部分（15,100 円/10 a）が, 2011 年度は米の所得補償交付金（15,000 円/10 a) のみが支払われた．制度加入の収入は，交付単価に 交付対象面積を乗じた額となる．作付面積あたりの 交付金は，自家消費米用の $10 \mathrm{a}$ が交付対象から除 外されているため, 作付面積規模が大きくなるほど, わずかずつであるが，増加している．

つぎに，制度加入の費用についてみる。まず，各 年度の作付面積から経営耕地面積までの作付面積の 拡大が自作地のみでなされる場合について，規模

表 1. 作付面積 $10 \mathrm{a}$ あたりの経営所得安定対策への加入の効果

\begin{tabular}{|c|c|c|c|c|c|}
\hline & \multirow{2}{*}{$\begin{array}{c}\text { 収入 } \\
\text { 交付金 }\end{array}$} & \multicolumn{2}{|c|}{ 費用 } & \multicolumn{2}{|c|}{ 純所得 } \\
\hline & & $\begin{array}{l}\text { 自作地のみ } \\
\text { による拡大 }\end{array}$ & $\begin{array}{l}\text { 小作地のみ } \\
\text { による拡大 }\end{array}$ & $\begin{array}{l}\text { 自作地のみ } \\
\text { による拡大 }\end{array}$ & $\begin{array}{l}\text { 小作地のみ } \\
\text { による拡大 }\end{array}$ \\
\hline \multicolumn{6}{|l|}{2010 年度 } \\
\hline $0.5 \sim 1.0$ ha & 25,960 & 62,012 & 56,148 & $-36,053$ & $-30,188$ \\
\hline $1.0 \sim 2.0$ ha & 27,991 & 33,256 & 28,559 & $-5,265$ & -568 \\
\hline $2.0 \sim 3.0$ ha & 28,869 & 17,243 & 13,242 & 11,626 & 15,628 \\
\hline $3.0 \sim 5.0$ ha & 29,304 & 17,670 & 11,160 & 11,633 & 18,144 \\
\hline 5.0 ha 以上 & 29,762 & 20,444 & 14,519 & 9,318 & 15,244 \\
\hline \multicolumn{6}{|l|}{2011 年度 } \\
\hline $0.5 \sim 1.0$ ha & 12,917 & 71,376 & 64,916 & $-58,459$ & $-51,999$ \\
\hline $1.0 \sim 2.0$ ha & 13,964 & 37,430 & 32,243 & $-23,466$ & $-18,279$ \\
\hline $2.0 \sim 3.0$ ha & 14,398 & 22,477 & 17,877 & $-8,079$ & $-3,479$ \\
\hline $3.0 \sim 5.0$ ha & 14,617 & 21,492 & 16,767 & $-6,875$ & $-2,151$ \\
\hline 5.0 ha 以上 & 14,822 & 31,549 & 24,882 & $-16,727$ & $-10,061$ \\
\hline
\end{tabular}

注：1）各年度の作付面積 $10 \mathrm{a}$ 当たりに換算して表示.

2）収入の交付金は，2010 年度は戸別所得補償モデル事業の定額部分と変動部分の合計であり，2011 年度は農業者戸 別所得補償制度の米の所得補償交付金である。 
階層ごとにみると，作付面積 $10 \mathrm{a}$ 当たりの費用は， 2010 年度, 2011 年度ともに, $0.5 \sim 1.0$ ha 層が最も 大きく, 次に大きい $1.0 \sim 2.0$ ha 層の 2 倍ほどとなっ ている. $0.5 \sim 1.0$ ha 層の費用が特に大きくなった のは, 制度に加入する場合の $0.5 \sim 1.0$ ha 層の米作 所得が負值となったためである。こ机らの次に費用 が大きかったのは，2010 年度，2011 年度ともに， 5.0 ha 以上層であった. 最も費用が小さかったのは, 2010 年度では $2.0 \sim 3.0$ ha 層であり, 2011 年度で は $3.0 \sim 5.0$ ha 層であった.

各年度の作付面積から経営耕地面積までの作付面 積の拡大が小作地のみでなされる場合についてみる と, 2010 年度, 2011 年度ともに, $0.5 \sim 1.0$ ha 層が 最も大きく, $1.0 〜 2.0$ ha 層が次に大きかった. 三 番目に費用が大きかったのは 5.0 ha 以上層であった. 最も費用が小さかったのは, 2010 年度, 2011 年度 ともに, $3.0 \sim 5.0$ ha 層であった.

以上のよらに, 各年度の作付面積から経営耕地面 積までの作付面積の拡大が自作地によるか, 小作地 によるかに関わらず, 制度加入の費用は, $0.5 \sim 1.0$ ha 層が最も大きく, $3.0 \sim 5.0$ ha 層, $2.0 \sim 3.0$ ha 層が 特に小さくなっていた.

全般に，これらの費用は，2010年度よりも 2011 年度の方が大きくなっているが，これは2011年産 米の米価が 2010 年産米の米価よりも高くなったた めである.

最後に, 制度加入の純所得についてみる. 自作地 による拡大か小作地による拡大かを問わず，2010 年度, 2011 年度ともに, 制度加入による純所得が 最も大きいのは $3.0 \sim 5.0$ ha 層であった．次に大き かったのは, $2.0 \sim 3.0$ ha 層であった. 以下, 5.0 ha 以上層, $1.0 \sim 2.0$ ha 層, $0.5 \sim 1.0$ ha 層と続いてい る.このため, 経営所得安定対策は, $3.0 \sim 5.0$ ha 層, $2.0 \sim 3.0$ ha 層という中規模層にメリットの大きい 政策となっている.

2010 年度と 2011 年度を比較すると, 制度加入の 純所得は 2010 年度の方が 2011 年度よりも大きくなっ ている.これは, 2010 年度では米価の下落が著しく, 変動部分が交付されて收入が増加したこと，また， 同時に，生産数量目標の達成による機会費用が小さ くなったことによる. その結果, 制度加入の純所得 は, 2011 年度ではすべての階層で負值であったが, 2010 年度では $2.0 \sim 3.0$ ha 層, $3.0 \sim 5.0$ ha 層, 5.0 ha
以上層の各階層で正值であった。

以上より, 経営所得安定対策は, 米価下落時に掠 注米作農家の収益性の改善に対して一定の効果を もつといえる。 しかし, 交付単価が規模間で一律で あることから，作付面積当たりの交付額の規模間で の差が小さく，また，生産数量目標の達成を要件と することによって，大規模層よりも中規模層に手厚 い政策となっている。 そのため, 経営所得安定対策 は米作の構造改革に逆行した政策になっていたとい らことができる。

以上のように, 本稿の推計では, 先行研究での大 規模層ほどメリットが大きいといら結果とは異なる 結果が得られた。 これは, 先行研究での試算では生 産調整のために失った米作所得を機会費用として考 慮していないためである。

\section{5. 結論}

本稿では, 米価が下落傾向にある中で, 米価の不 確実性による影響の低減を目的に実施されている経 営所得安定対策（戸別所得補償）が米作農家の収益 性に及湆す効果について考察し, 米作の構造改革へ の影響について検討することを課題とした，そのた め, 戸別所得補償モデル対策, 農業者戸別所得補償 制度が実施された 2010 年度と 2011 年度を対象とし て，制度加入による交付金収入から制度加入の要件 である生産数量目標達成の機会費用の差を制度加入 の純所得と定義して考察した.

生産数量目標達成の機会費用は, 経営耕地面積す べてに作付けた場合の米作所得と各年度の米作所得 の差, すなわち, 生産調整によって失った米作所得 と定義して，草苅・中川（2011）の計測結果を援用 して推計した，その結果，制度加入の純所得は中規 模層（3.0〜 5.0 ha 層）が最も大きくなっていた. また，米価変動交付金（変動部分）が交付されるほ ぞ米価が下落している場合は，米価変動交付金が交 付されない場合に比べて，制度加入の純所得が大き くなっていたことがわかった，そのため，経営所得 安定対策は, 米価下落時の米作農家の収益性の改善 に対して一定の効果をもつものの, 交付単価が規模 間で一律であり, 生産数量目標の達成が加入要件で あるため，大規模層よりも中規模層に手厚い政策と なり，米作の構造改革に逆行する政策になっていた ことが明らかになった。 
先行研究に打いては, 戸別所得補償（経営所得安 定対策）は規模拡大のインセンティブとなることが 指摘されていた。一方, 本稿では, 生産調整のため に失った米作所得を機会費用として考慮したことに より，先行研究とは逆の結果となった。

付記 本稿は, 科学研究費助成事業 (学術研究助 成基金助成金）（若手研究（B)），課題番号 25850150 による研究成果の一部である。

注 1) 本研究は現行制度が米作所得の得失に及ぼす効果 について分析したものである，一方，政府は，2013 年11月 26 日の農林水産業・地域の活力創造本部で, 経営所得安定対策の見直し（米の直接支払交付金 の 2014 年産米からの減額と 2018 年産米からの廃 止, 米価変動補填交付金の 2014 年産米からの廃止) と, 5 年後を目途にコメの生産数量目標の配分を 廃止することを決定した，本研究ではこうした制 度変更の効果は考慮していない。

2) 草苅（1989）は，追加的な減反によって農家が衰 失した米作所得を減反の機会費用と定義して, 減 反政策の経済性について分析している.

3）交付の基準となる「標準的な販売価格」は2010 年度 ～ 2012 年度で共通の 11,978 円 $/ 60 \mathrm{~kg}$ とされている.

4）機械を可変要素としたのは, 作業受委託などによっ て，フローとしての機械用役の投入量の調整が可 能であると考えられるためである.

5）草苅・中川（2011）に従って，物財費に含まれる 減価償却費は 1990 年以前の系列に接続するよう調
整している.

6）推計方法とデータについては，草苅・中川（2011） の（註 13）を参照のこと.

7）ここで算出した地代や小作地の実勢地代は，作付面 積規模間に格差がある. 経営耕地面積すべてに作付 面積を拡大寸る場合，規模階層を移動することにな るが，それに伴ら地代の調整は行わなかった。

\section{引用文献}

藤野信之(2011)「米戸別所得補償モデル事業の動向」 『農林金融』64(4)，34-43.

磯田宏（2011）「米戸別所得補償モデル事業の実績 と課題」梶井功編集代表・谷口信和編集担当 『民主党農政 1 年の総合的検証一新基本計画か ら戸別所得補償本対策へ一』（日本農業年報 57)，農林統計協会，75-89.

草苅 仁（1989）「稲作農家の規模階層からみた減 反政策の経済性」『農業経済研究』61(1)，1018.

草苅 仁・中川聡司（2011）「不完全競争市場に招 汀る米作農家の借地行動一取引費用之不確実性 の影響分析一」『農業経済研究』83(1)，28-42.

谷口信和（2010）「米政策から水田農業政策へ一戸 別所得補償モデル対策の意義と課題一」梶井 功編集代表・矢坂雅充編集担当『民主党農政 一政策の混迷は解消されるのか一』（日本農業 年報 56)， 87-112.

（受理日：2014 年 2 月 13 日） 